\title{
OPTIMIZING A MULTI-TIO 2 BASED ELECTRON TRANSPORT LAYER FOR PEROVSKITE SOLAR CELLS
}

\author{
Kazuhiro Manseki ${ }^{1}$, Shinapol Toranathumkul ${ }^{1}$, Catlin Ethridge $^{2}$, Takashi Sugiura ${ }^{1}$, Saeid Vafaei ${ }^{2 *}$ \\ ${ }^{1}$ Department of Chemistry and Biomolecular Science, Gifu University, Gifu, Japan. \\ ${ }^{2}$ Bradley University, Mechanical Engineering Department, Peoria, IL, USA.
}

\begin{abstract}
The purpose of this paper is to manufacture perovskite solar cells (PSC) employing an $\mathrm{TiO}_{2}$ electron transport layer that consists of two different $\mathrm{TiO}_{2}$ particles. Anatase $\mathrm{TiO}_{2}$ nanoparticles with the dimensions of $\sim 5 \mathrm{~nm}$ were synthesized at a low temperature using dimethylformamide as a structure directing agent. Hydrolysis of $\mathrm{TiCl}_{4}$ and subsequent $\mathrm{TiO}_{2}$ crystal growth were controlled without using conventional hydrothermal methods. Ethanol based nanofluids containing a mixture of commercial anatase $\mathrm{TiO}_{2}$ particles with the dimensions of $20 \mathrm{~nm}$ and the tiny $\mathrm{TiO}_{2}$ particles were prepared to create the multi- $\mathrm{TiO}_{2}$ based electron transport layer. In first step for the device assembly, a buffer layer (compact $\mathrm{TiO}_{2}$ layer) was spin-coated and subsequently sintered to stabilize particles on FTO glass. Secondly, the newly prepared $\mathrm{TiO}_{2}$ nanofluid was deposited, using spin coater technique and sintered to form the electron transport layer. The light absorber Perovskite and SpiroOMeTAD (hole transport material) were successively deposited with a spin-coater in a glove box at a humidity of less than $20 \%$. Finally, a gold layer was deposited on top of the Spiro-OMeTAD. A systematical change of the ratio of adding different size $\mathrm{TiO}_{2}$ particles was examined to optimize the anatase $\mathrm{TiO}_{2}$ electron transport layer in PSC. In addition, the characteristics of other deposited layers were also optimized to maximize the efficiency of PSC. The device performance of PSC was tested under 1 sun light condition using a solar simulator.
\end{abstract}

KEY WORDS: $\mathrm{TiO}_{2}$ Nanoparticles, Perovskite Solar Cell, Sintering

\section{INTRODUCTION}

Currently, perovskite solar cells (PSC) consisting of halide perovskite compounds, referring to $\mathrm{ABX}_{3}$ (A: organic cation or metal ion, $\mathrm{B}$ : metal ion, and $\mathrm{X}$ : halide anion), have been a center of research interest in the field of emerging photovoltaic technologies [1]. This is because of the wide-band light absorption of the materials from visible to near IR region of $\sim 800 \mathrm{~nm}$ (typical characteristics for $\mathrm{CH}_{3} \mathrm{NH}_{3} \mathrm{PbI}_{3}$ ) and very efficient charge transport properties of electrons and holes by light irradiation. Furthermore, the perovskite materials can be deposited from solution, and it is expected to produce large area modules of the perovskite solar cells at low-cost. One of the commonly used device structures is the integration of oxide semiconductor nanoparticles, such as Titanium dioxide $\left(\mathrm{TiO}_{2}\right)$, onto transparent conducting glasses [2]. They are used as the electron transport layer, which is at the bottom of the perovskite layer. For such $\mathrm{TiO}_{2}$ applications to work effectively, the generated electrons and/or holes must be mobile enough inside the $\mathrm{TiO}_{2}$ layer. To avoid recombination of the photocarriers, there has been extensive research on the chemical synthesis of highlycrystallized $\mathrm{TiO}_{2}$ particles with various nanostructures. Notably, design of nano-crystalline $\mathrm{TiO}_{2}$ films have received much attention in order to understand the relationship between size, shape, crystal facets, crystal phase of $\mathrm{TiO}_{2}$ particles and device performance. The focus of these studies has often been paid to the 
performance of electron extraction and transport in PSC. Recent examples show that there are several parameters of the $\mathrm{TiO}_{2}$ particles that have potential to greatly improve the device performance. They include the use of sintered rutile $\mathrm{TiO}_{2}$ as the electron transport layer, having a relatively high electron mobility, where recombination at the interface between $\mathrm{TiO}_{2}$ and perovskite could be effectively suppressed to exhibit a high open-circuit voltage of $1.17 \mathrm{~V}$ in PSC [3]. Vertical anatase $\mathrm{TiO}_{2}$ nanotube arrays have also been applied to give improved photocurrents as compared to the conventional flat $\mathrm{TiO}_{2}$-based PSCs [4].

Our aim was to investigate the effect of the mixed $\mathrm{TiO}_{2}$ layers with different structural characteristics on the photovoltaic performance of PSC. Recently, we have demonstrated that the mixture of brush-shaped $\mathrm{TiO}_{2}$ $(\sim 100 \mathrm{~nm})$ and tiny $\mathrm{TiO}_{2}$ nanoparticles $(\sim 6 \mathrm{~nm})$ produced a favorable photo-electrode material for dyesensitized solar cells [5], where the small particles played an important role in the enhancement of the connection of $\mathrm{TiO}_{2}$ particles during the sintering process. We anticipated that the similar concept of the addition of tiny $\mathrm{TiO}_{2}$ particles will lead to the improvement of photovoltaic performance of PSC, working as the effective electron transport layer. Here we focus on the use of multi- $\mathrm{TiO}_{2}$ nanofluid containing commercial anatase nanocrystals $(\sim 20 \mathrm{~nm})$ and our original anatase $\mathrm{TiO}_{2}(\sim 5 \mathrm{~nm})$. The improved performance of PSC is presented for the device of a multi- $\mathrm{TiO}_{2}$ system.

\section{EXPERIMENTAL}

\section{Assembly of Perovskite Solar Cell}

We assembled Perovskite solar cell as follows using the modified method that has been reported previously [6]:

I. Depositing buffer layer on FTO glass. Vacuum pump for spin-coater (MIKASA MS-A100) was turned on, speed was adjusted to $5000 \mathrm{rpm}$ and running time to 30 seconds. FTO glass was securely positioned in the center of spin coater rotating plate. The buffer layer solution of 2, 2Iminodiethanol $(0.14 \mathrm{~g})$, Ethanol $(2.5 \mathrm{~mL})$, and Titanium Isopropoxide (TTIP) $(0.36 \mathrm{~g})$ was then delivered to the FTO glass by pipet until glass was fully covered (approximately 8-12 drops). This buffer layer would strengthen the ability for deposited $\mathrm{TiO}_{2}$ particles to remain in contact with the solid surface of the FTO glass. The FTO surface was coated by placing the lid on the spin coater, and letting the spin coater run for the set speed and time. The FTO glass was then dried in an oven at $500^{\circ} \mathrm{C}$ for 60 minutes.

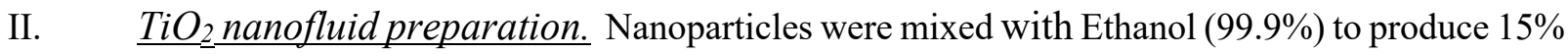
by mass concentration of nanofluid. The nanoparticles were combination of commercial PST$18 \mathrm{NR}(\sim 20 \mathrm{~nm})$ and tiny $\mathrm{TiO}_{2}(\sim 5 \mathrm{~nm})$ with Anatase crystal phase. The concentration of smaller $\mathrm{TiO}_{2}$ with Anatase crystal phase was $1 \mathrm{wt} \%$. Cap was screwed on and container was placed in a Conditioning Mixer (THINKY AR-250). Mixer was set for 2 minutes, once finished set for another 2 minutes, total of 4 minutes of mixing.

III. $\quad \mathrm{TiO}_{2}$ deposition. Tape was carefully placed on opposite edges of the dried FTO glass measuring probes would be placed later. FTO glass was then carefully and securely lowered into the spin coater for the second time. The previously prepared nanofluid was then deposited onto prepared FTO glass by pipet until the glass was fully covered (approximately 8-12 drops). To fully coat the prepared FTO glass, the lid was placed on the spin coater ran at $1500 \mathrm{rpm}$ for 30 seconds. The sample was then dried by running the spin coater at $1000 \mathrm{rpm}$ for 60 seconds. After spin coating, the tape was removed from the FTO glass and the glass was then placed on a hot plate to dry at $120^{\circ} \mathrm{C}$.

IV. Sintering process. FTO glass with $\mathrm{TiO}_{2}$ particles deposited was placed in an electric oven to sinter the substrate. Beginning at room temperature, the substrate was heated to $500^{\circ} \mathrm{C}$ (maximum temperature). The temperature was increased to $325^{\circ} \mathrm{C}$ in $10 \mathrm{~min}$. and keep for 5 min., then increased to $375^{\circ} \mathrm{C}$ in $10 \mathrm{~min}$. and keep for 5 minutes, followed by increasing the temperature to $450^{\circ} \mathrm{C}$ in $10 \mathrm{~min}$. and keep for $5 \mathrm{~min}$. Lastly, the temperature was raised to $500^{\circ} \mathrm{C}$ in $10 \mathrm{~min}$. and keep for $15 \mathrm{~min}$. The substrate was allowed to cool on its own. 
V. $\quad \mathrm{TiCl}_{4}$ treatment. In a glove box with low humidity (less than $20 \%$ ), the samples were placed inside the glass sample holder, Fig. 1. The $\mathrm{TiCl}_{4}$ was massed on a scale, inside fume hood, in a graduated cylinder $(1.39 \mathrm{~g})$. Still under the fume hood, water was added to and mixed well with the $\mathrm{TiCl}_{4}(120 \mathrm{~mL})$. This mixture was then poured into the sample holders so that all of the samples were covered completely with the $\mathrm{TiCl}_{4}$ mixture. After the sample containers were placed in the oven, they were left to heat for 30 minutes at $60^{\circ} \mathrm{C}$. Once heating was completed, the liquid was poured out and the samples were washed thoroughly (about 3 times) with deionized water. After washing, samples were removed one at a time and washed individually with water then left to dry.

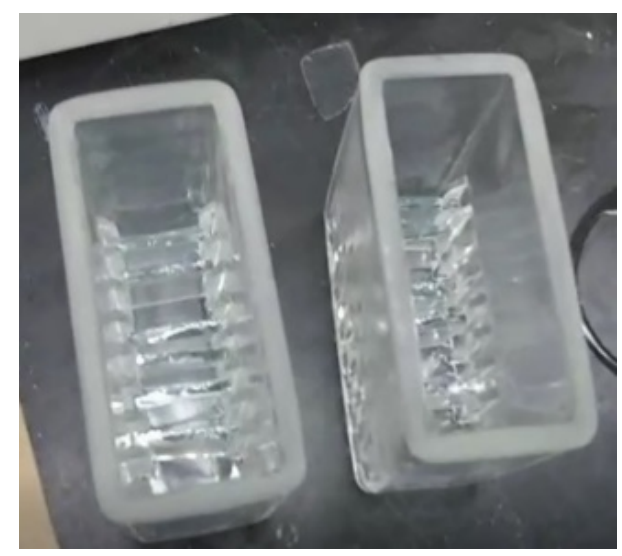

Fig. 1 Sample Holder

VI. Perovskite solution. First, the Perovskite solution was made in a controlled environment with low humidity (less than 20\%) and filled with Nitrogen. Dimethylformamide (DMF) and Dimethyl Sulfoxide (DMFO) were mixed 6:4 by volume. With CsI (0.0168 g), $\mathrm{PbI}_{2}(0.5441 \mathrm{~g})$, Formamidinium Iodide (FAI) (0.1805), Methylammonium Bromide (MABr) (0.0244 g), and $\mathrm{PbBr}_{2}(0.0680 \mathrm{~g}), 1 \mathrm{~mL}$ of the DMF/DMFO solution was mixed to make the Perovskite solution. The Perovskite solution was then deposited on the treated FTO glass (Fig. 2), in the same environment (at low humidity, less than $20 \%$ ) that the solution was prepared, using a specific process. The FTO glass with $\mathrm{TiO}_{2}$ particles $\left(\mathrm{FTO}-\mathrm{TiO}_{2}\right)$ was obtained from a hot plate where the glass was kept at $80^{\circ} \mathrm{C}$ for $60 \mathrm{~min}$. prior to the deposition process to reduce amount of moisture. Once the treated FTO glass was ready it was placed on a hot plate to heat for $10 \mathrm{~min}$. at $55^{\circ} \mathrm{C}$. The $\mathrm{FTO}^{-\mathrm{TiO}_{2}}$ glass was then carefully placed on the rotating plate of the spin coater where the Perovskite solution was deposited on the glass by a pipet until glass was fully coated (8-12 drops) and left to calm for 70 seconds. The spin coater was then ran at $3500 \mathrm{rpm}$ for 30 seconds where after 10 seconds of spinning Anisole $(0.3 \mathrm{~mL})$ was dropped onto glass. Once spinning was complete, the $\mathrm{FTO}-\mathrm{TiO}_{2}$ glass was moved from the spin coater to a hot plate where it was heated for $10 \mathrm{~min}$. at $155^{\circ} \mathrm{C}$ then allowed to cool to room temperature (Fig. 3).

VII. Spiro-OMeTAD solution (Hole transport layer). To make the Spiro-OMeTAD solution, Spiro-OMeTAD (0.0528 g) was mixed with Chlorobenzene $(0.64 \mathrm{~mL})$, 4-tert-Butylpyridine (TBP) $(14.4 \mu \mathrm{L})$, and a LiTFSI $(0.500 \mathrm{~g})$ in Acetonitrile $(1 \mathrm{~mL})$ mixture. After preparing the mixture, the $\mathrm{FTO}-\mathrm{TiO}_{2}$ glass with previously deposited Perovskite solution was placed on the spin coater, in the same environment for Perovskite solution deposition, where 2 drops of the Spiro-OMeTAD solution is deposited on the middle of the glass. The spin coater is then ran for 30 seconds at $3000 \mathrm{rpm}$. After coating, the $\mathrm{FTO}^{-\mathrm{TiO}_{2}}$ glass remained untouched for one night in dry air (Fig. 4). 


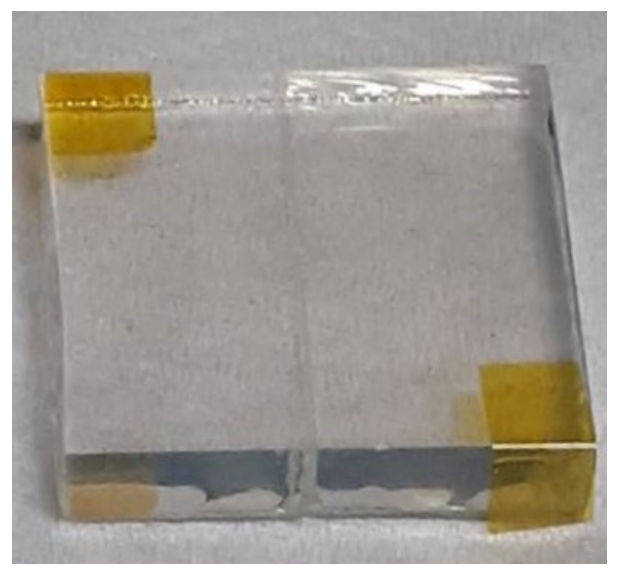

Fig. 2 FTO substrate before Perovskite deposition.

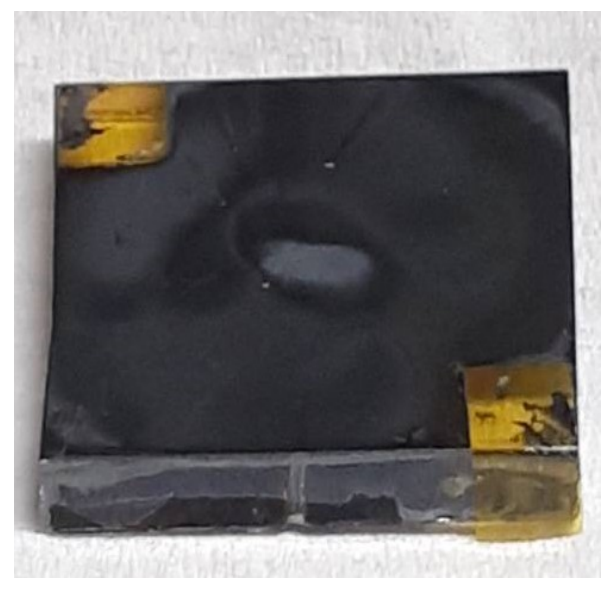

Fig. 3 FTO substrate after Perovskite deposition.

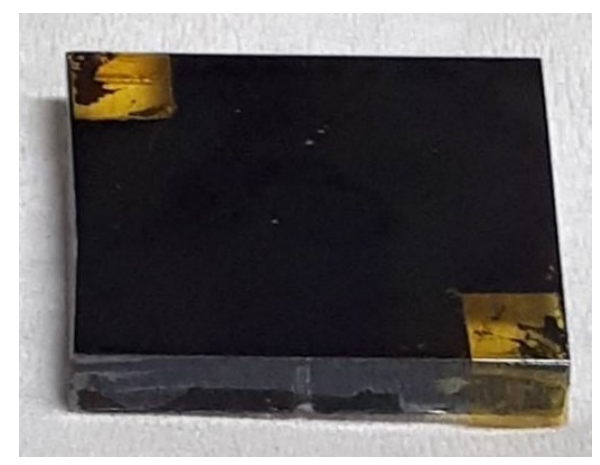

Fig. 4 FTO substrate after deposition of Spiro-Ometad solution.

VIII. Making a counter electrode. The previously prepared FTO glass was attached to a metal mask using tape to prepare the substrate for gold deposition. These glass/mask pieces were then taped to the lid of the thermal evaporation deposition machine with the glass against the lid as seen in fig. 5. After all samples are in place, the plate arm was swung over to cover the samples. The edge of the chamber was then greased for a good seal and the lid was gently lowered and latched tightly. To start this machine the vacuum was first turned on, the pressure was stabilized, and finally the pump was turned on. The gold wire that was placed on the electric heater was $0.058 \mathrm{~g}$ in the optimization of spin- 
coating of perovskite solution and Spiro-Ometad solution. The gold wire of $0.19 \mathrm{~g}$ was used for assembling the multi- $\mathrm{TiO}_{2}$ based solar cell. This gold was left to melt inside the Thermal Evaporation Deposition Machine where the melting temperature was tuned by adjusting the current. For this project, the current was increased to $78 \mathrm{~A}$ to melt the gold. Once gold is melted inside the scoop, the current was turned off, the main valve closed, the pressure was reduced and then the machine was turned off. This machine allowed for the melted gold to be deposited through the holes of the masks covering the FTO glass, the thickness of this deposition can be changed based on how much gold is in the scoop.

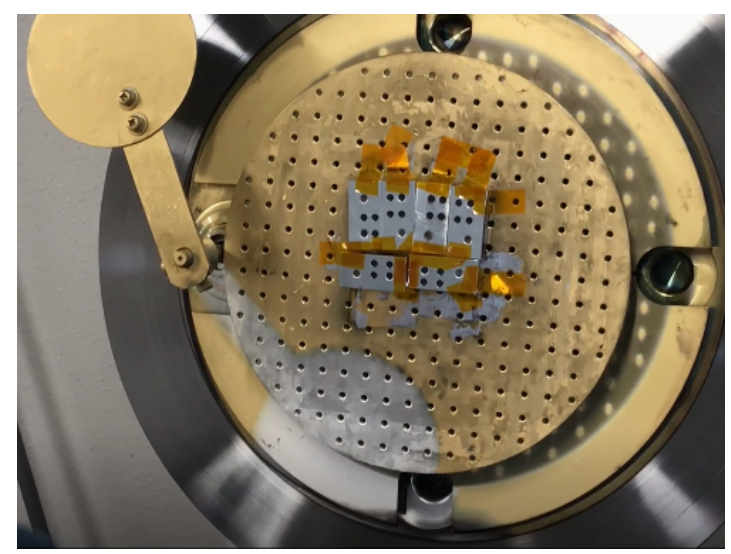

Fig. 5 Thermal Evaporator lid.

IX. Measurement of current-voltage curves. After the counter electrode has been made the I-V curves of these cells were tested by using a Solar Simulator (YSS-80A). The sample was connected to the Solar Simulator with measuring probes where the gold was deposited and placed under the light of the machine. A potentiostat (Hokuto Denko) equipped with the solar simulator created a current vs voltage graph and that data was collected. The measurement was carried out under 1 sun light condition. The active area of device was set to $0.07 \mathrm{~cm}^{2}$.

\section{Sintering and Structure Analysis of Sintered $\mathrm{TiO}_{2}$ Particles:}

A programable electric furnace (300-plus, KDF) was used for sintering $\mathrm{TiO}_{2}$ particles. The images of deposited porous layer of multi- $\mathrm{TiO}_{2}$ nanoparticles were captured by scanning electron microscope (S-4800) after sintering.

\section{RESULTS AND DISCUSSIONS}

Fig. 6a and $6 \mathrm{~b}$ show typical SEM images of the surface of $\mathrm{TiO}_{2}$ substrate consisting of multi- $\mathrm{TiO}_{2}$ film of two different size particles $(\sim 5 \mathrm{~nm}$ and $\sim 20 \mathrm{~nm})$. It turned out that a heating process at $500{ }^{\circ} \mathrm{C}$ enhanced fusion of individual particles, producing a $\mathrm{TiO}_{2}$ particles layer with a relatively low porosity. It is likely from the SEM image that smaller $\mathrm{TiO}_{2}$ particles helped the sintering of larger particles, leading to the formation of larger grains $(50 \sim 200 \mathrm{~nm})$ in the film. Similar fusion was also observed in our previous study on dye-sensitized solar cells using the sintering of the multi- $\mathrm{TiO}_{2}$ nanofluids of rutile $\mathrm{TiO}_{2}$ particles and tiny anatase $\mathrm{TiO}_{2}$ particles [5]. We also found that such a fusion occurred homogenously in the whole area of $\mathrm{TiO}_{2}$ film. 
(a)

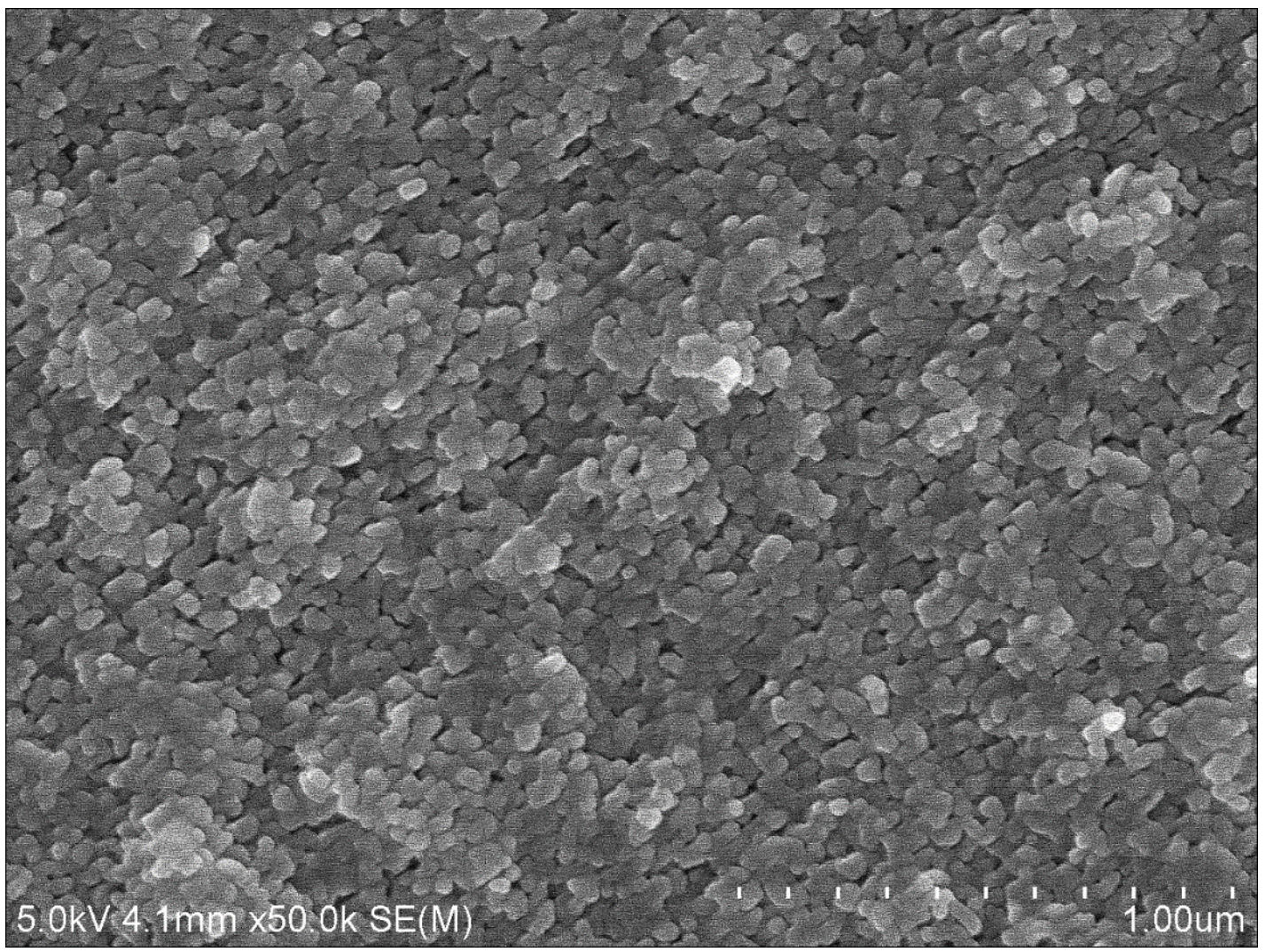

(b)

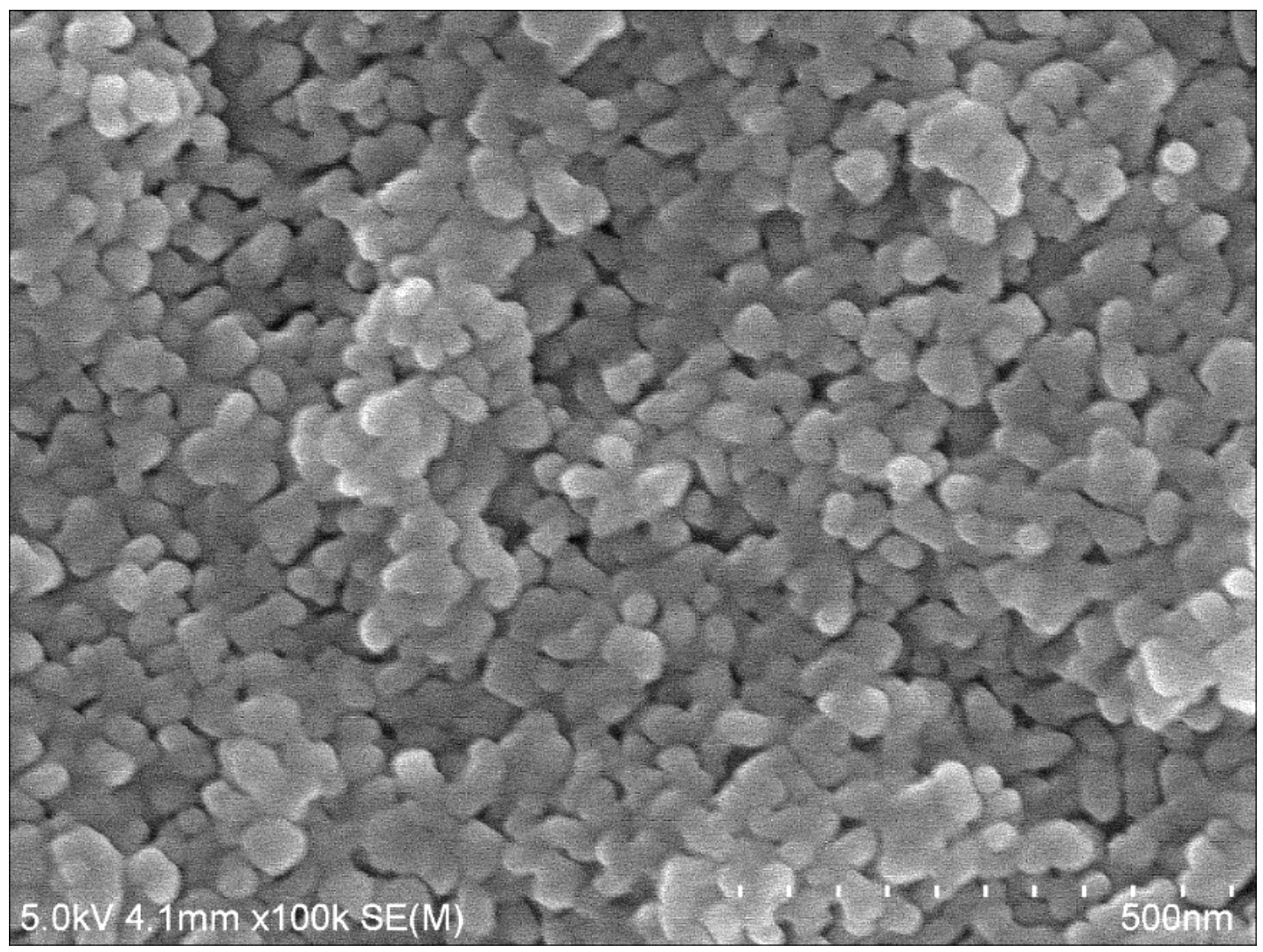

Fig. $6 \mathrm{~A}$ SEM image of the surface of $\mathrm{TiO}_{2}$ substrate consisting of $2 \mathrm{wt} \% 5 \mathrm{~nm}-\mathrm{TiO}_{2}$ in the multi- $\mathrm{TiO}_{2}$ film: (a) low magnification image and (b) high magnification image. 
In regards to the $\mathrm{TiO}_{2}$ application in Perovskite solar cells, we first optimized a method of preparing the $\mathrm{TiO}_{2}$ film containing only $20 \mathrm{~nm}-\mathrm{TiO}_{2}$ particles. As shown in Table 1 , spin-coating strategy of the perovskite solution was varied from $2500 \mathrm{rpm}$ to $5000 \mathrm{rpm}$. The highest efficiency was from $3500 \mathrm{rpm}$ condition. In addition, spin-coating strategy of the Spiro-OMeTAD solution was changed from $1500 \mathrm{rpm}$ to $4000 \mathrm{rpm}$. The maximum efficiency was obtained when the coating speed was $3000 \mathrm{rpm}$. With these in mind, we adapted the multi- $\mathrm{TiO}_{2}$ electron transport layer to Perovskite Solar Cell. When the concentration of $5 \mathrm{~nm}-\mathrm{TiO}_{2}$ was $1 \mathrm{wt} \%$, the solar cell's efficiency was found to be $16.4 \%$ with $\mathrm{V}_{\text {oc }}$ of $1040 \mathrm{mV}, \mathrm{J}_{\mathrm{sc}}$ of $21.2 \mathrm{~mA} / \mathrm{cm}^{2}$ and F.F. of 0.742 , whereas the efficiency of $13.4 \%$ with $\mathrm{V}_{\text {oc }}$ of $1000 \mathrm{mV}, \mathrm{J}_{\mathrm{sc}}$ of $21.5 \mathrm{~mA} / \mathrm{cm}^{2}$ and F.F. of 0.623 was observed for non- $5 \mathrm{~nm}-\mathrm{TiO}_{2}$. This efficiency increase is probably due to the well-interconnected $\mathrm{TiO}_{2}$ layer of $\mathrm{multi}^{-\mathrm{TiO}_{2}}$ film that contributes to an efficient electron transport in the $\mathrm{TiO}_{2}$ film. The higher F.F. suggested the improved charge transport in the multi- $\mathrm{TiO}_{2}$ layer of the device. the Effect of concertation of the tiny $\mathrm{TiO}_{2}$ particles with Anatase crystal phase on Perovskite solar cell efficiency is in progress.

Table 1. The effect of deposition condition of Perovskite layer on Perovskite solar cell efficiency.

\begin{tabular}{|c|c|c|c|c|}
\hline $\begin{array}{c}\text { Deposition } \\
\text { condition of } \\
\text { perovskite layer }\end{array}$ & $\mathbf{V}_{\mathbf{o c}}$ & $\mathbf{J}_{\text {sc }}$ & F.F. & $\begin{array}{c}\text { Perovskite Solar } \\
\text { Cell Efficiency }\end{array}$ \\
\hline $\begin{array}{c}\text { Spin-coating (2500 } \\
\text { rpm) }\end{array}$ & 945 & 20.5 & 0.507 & $9.82 \%$ \\
\hline $\begin{array}{c}\text { Spin-coating (3500 } \\
\text { rpm) }\end{array}$ & 970 & 21.8 & 0.524 & $11.1 \%$ \\
\hline $\begin{array}{c}\text { Spin-coating (5000 } \\
\text { rpm) }\end{array}$ & 992 & 20.4 & 0.527 & $10.7 \%$ \\
\hline
\end{tabular}

Table 2. The effect of deposition condition of Spiro-OMeTAD layer on Perovskite solar cell efficiency.

\begin{tabular}{|c|c|c|c|c|}
\hline $\begin{array}{c}\text { Deposition condition of } \\
\text { Spiro-OMeTAD Layer }\end{array}$ & $\mathbf{V}_{\text {oc }}$ & $\mathbf{J}_{\text {sc }}$ & F.F. & $\begin{array}{c}\text { Perovskite Solar Cell } \\
\text { Efficiency }\end{array}$ \\
\hline Spin-coating $(1500 \mathrm{rpm})$ & 926 & 20.4 & 0.529 & $9.99 \%$ \\
\hline Spin-coating $(3000 \mathrm{rpm})$ & 974 & 21.5 & 0.616 & $12.9 \%$ \\
\hline Spin-coating $(3500 \mathrm{rpm})$ & 965 & 22.7 & 0.586 & $12.8 \%$ \\
\hline Spin-coating $(4000 \mathrm{rpm})$ & 771 & 18.6 & 0.456 & $6.54 \%$ \\
\hline
\end{tabular}

\section{CONCLUSION}

Multi- $\mathrm{TiO}_{2}$ particles-based nanofluids (containing two different size particles) enabled us to obtain a relatively dense $\mathrm{TiO}_{2}$ layer in the sintering process, with the help of tiny $\mathrm{TiO}_{2}$ particles. In addition, spincoating strategies of the anatase $\mathrm{TiO}_{2}$ layer was investigated for optimizing the performance of Perovskite Solar Cell. The multi- $\mathrm{TiO}_{2}$ electron transport layer showed a higher light-to-electricity conversion efficiency compared to that of single $\mathrm{TiO}_{2}$ layer. Further optimization changing the sintering strategies of the multi-TiO particles are in progress in our group.

\section{ACKNOWLEDGMENT}

This work was supported by the Koshiyama Research Grant and JSPS KAKENHI Grant no. 15K05664 in Japan and Illinois Space Grant Consortium, USA. 


\section{REFERENCES}

[1] Jena, A.-K., Kulkarni. A, Miyasaka, T., "Halide Perovskite Photovoltaics: Background, Status, and Future Prospects", Chem. Rev., 119(5), pp. 3036-3103, (2019).

[2] Bai, Y., Mora-Seró. I., Angelis, F.-D., Bisquert, J., Wang. P., "Titanium Dioxide Nanomaterials for Photovoltaic Applications", Chem. Rev., 114(19), pp. 10095-10130, (2014).

[3] Wang, Y., Wan. J., Ding, J., Hu, J.-Song, Wang. D., “A Rutile $\mathrm{TiO}_{2}$ Electron Transport Layer for the Enhancement of Charge Collection for Efficient Perovskite Solar Cells", Angew. Chem. Inter. Ed., 58, pp. 1-6, (2019).

[4] Liang, X., Cheng. Y., Xu, X., Dong, Ruoting., Li. D., Zhou, Z., Wei. R., Dong, G., Tsang, S.-W., Ho, J.-C., "Enhanced Performance of Perovskite Solar Cells Based on Vertical $\mathrm{TiO}_{2}$ Nanotube Arrays with Full Filling of $\mathrm{CH}_{3} \mathrm{NH}_{3} \mathrm{PbI}_{3}$, $\mathrm{Appl}$. Surf. Sci., 451, pp. 250-257, (2018).

[5] Vafaei, S., Manseki, K., Horita, S., Matsui, M., Sugiura, T., "Controlled Assembly of Nanorod $\mathrm{TiO}_{2}$ Crystals Via A Sintering Process: Photoanode Properties In Dye-Sensitized Solar Cells", Inter. J. Photoenergy, 7686053, (2017).

[6] Zhao, P., Kim. Kim, B.-J., Ren, X., Lee, D.-G., Bang, G.-J., Jeon, J.-B., Kim, W.-B., Jung, H.-S., “Antisolvent With An Ultrawide Processing Window For The One-Step Fabrication of Efficient And Large-Area Perovskite Solar Cells", $A d v$. Mater, 30, 1802763, (2018). 